\title{
Understanding project mobility: the movement of King's Cross to Brussels and Johannesburg
}

\begin{abstract}
This paper builds on policy mobility research to question how loosely deployed references to specific models or sites reveal how tacit and explicit knowledge are required to effectively replicate urban ideas in new places. Departing from existing analysis of policies and the public sector, we use policy mobility framing to critically engage with the strategies of the private sector. We analyse King's Cross' arrival in two large-scale redevelopments: Brussels' Tour and Taxis and Johannesburg's Modderfontein, questioning how it was referred to, the success of its deployment and the politics of urban learning. We draw three main conclusions: firstly, the comparison demonstrates private sector agency in their ability to shape the way expert knowledge arrives. Secondly, we argue that private sector actors require locally embedded practices and tacit knowledge to leverage international points of reference in their projects. Thirdly, in placing the analytical gaze from the perspective of the project 'arriving' and adopting a specifically comparative approach, we reveal the myriad of possibilities developers and consultants face and the politics of what they pick from each. Theoretically, these conclusions draw from economic geography's politics of learning and mobility research to demonstrate the benefit of analysis that traces a project, rather an idea or a policy, and from 'arriving at' and the subsequent assembling of different project components.
\end{abstract}

\section{Key Words}

Project mobility, Real estate developers, London, Brussels, Johannesburg 


\section{Introduction}

The redevelopment of London's King's Cross has become emblematic of successful regeneration, sustainable development and transit orientated development (ToD), evidenced in its deployment as a model for new developments elsewhere. Within the overall development there are a number of sites, with King's Cross Central is the most recognisable and researched part in academia (cf. Edwards, 2009; Robin, 2018). In contrast, beyond academia the site is often referenced more broadly by real estate professionals. In this paper we draw on policy mobility research to question how King's Cross is mobilised by developers and consultants in other locations. We follow King's Cross to Tour and Taxis (T\&T), Brussels and Modderfontein, Johannesburg. In looking across all three sites, we seek to broaden the debate on the global nature of urban processes to demonstrate how it is possible to 'follow the project'. In doing so it becomes evident that King's Cross is simplified into a set of standardised, translatable elements which mutes the realities of development into a more reductive idea about what the development can or does represent to other consultants and developers. By analysing the similarities and differences in its deployment in the two new sites, we demonstrate the politics of urban mobility and learning.

T\&T has a long history that dates back to the $16^{\text {th }}$ century when it was owned by the family Von Thurn and Tassis, an aristocratic Brussels' family of Austrian origin who stood at the root of a late pan-European transportation network (Van Criekingen and Vandermotten, 2007; La Fonderie, 2010). In 1704 the property passed into the hands of the Southern German Real Estate Company, a company 'responsible for the founding of the European Postal Service' (La Fonderie, 2010: 24), and then around 1890, to the Société du Canal (the City of Brussels) and the Belgian State (Minister of Finance and the National Railway Company -SNBC-). It is a 37 ha site built between 1902 and 1907 which accommodated, for almost ninety years, a multi-modal platform (Brussels' in-port, a railway station and yards) for the distribution of goods, their storage in warehouses, and the collection of duties and taxes. The complex is favourably located next to the centre of the Brussels Capital Region and lies within the Canal Area, a physical barrier between the wealthy east and disadvantaged west (Vermeulen, 2015; BRAL, 2017). The site was initially publicly owned, but was gradually sold to private companies from the early 1990s. Since then, a number of projects were proposed for the area (cf Van Criekingen and Vandermotten, 2007; Vermeulen, 2015), which all aimed to transform it into a mix of new functions and spaces. The acquisition of the property by the Extensa Group in 2015 signalled a turning point, and the company started to promote its own vision of T\&T: a new eco- neighbourhood. Despite T\&T's historical function as an infrastructure and logistics node, the re-design of the area had not previously included the reactivation of the old train station. However, given the railway structure's historical prestige, Extensa Group's recent masterplan includes its restoration and transformation into space comprising of gardens, and co-working, retail, and leisure spaces. Within their plan, King's Cross was mobilised by the developer for two reasons: as a symbol of a successful combination of historical heritage and modern architectures and as the case that best represents the length and complexity of large-scale urban interventions (Interview with the current developer \#2, 2018). 
Modderfontein in north-east Johannesburg has experienced 30 years of attempted development, much of which, at least for the last decade, was premised on the idea of eventually building a train station. In 2012, a Shanghai developer, Zendai, purchased the site with aspirations of building a new node in the global economy. To implement this plan, Zendai hired consultants largely from outside South Africa (Brill, 2018; Ballard and Harrison, 2018), led by Atkins, and including Arup and Colliers International. Each prided themselves on their ability to draw from other contexts to feed into a masterplan submitted to the planning authority, the City of Johannesburg (CoJ), in 2016, for a mixed-use area. In 2017, despite reservations about the plan, CoJ put it to planning council. The plan has been analysed as trans-national urbanism interrupted and as an example of failed localisation (Ballard and Harrison, 2018; Ballard et al., 2017; Brill, 2018). This paper seeks to build on this analysis by questioning the tools (not just actions) at the developers' disposal in Modderfontein. Going forward, as M\&T takeover the site, the expectation of those interviewed was that the project will change (interview with consultant \#4, 2018), but despite this M\&T are currently developing industrial sites in the southern end of the site, which are advertised based on their proximity to a new train station.

Drawing on the similarities and differences of Modderfontein and T\&T, this paper responds to McCann and Ward's (2015) call to put into conversation sites of success and failure, to engage with underlying differences. Juxtaposing the sites and speaking across their experiences allows us to "reflect critically on approaches to success/failure and their relational constitution" (McCann and Ward, 2015: 828). This paper therefore builds on existing research on policy mobility and emerging work on the mobility of ideas (see Watson, 2014; Bok and Coe, 2017; Rapoport and Hult, 2017), to 'follow the project' within the private sector. In particular, we develop on Gonzalez's (2011) research on Barcelona and Pow's (2014; 2018) on Singapore, by focusing specifically on the arrival of a model, in this case the King's Cross model. By comparing Modderfontein and T\&T, where the same model arrives but is evoked with significantly different outcomes, we see how the selective leveraging of codified best practices reveals how circulating ideas are symbolic and political.

This comparison is particularly pertinent because of the nature of the projects researched. King's Cross was a huge regeneration site with significance for London specifically, and the UK as a whole. In Brussels, T\&T is also a regeneration site which borders the divided east and west of the city. Sitting along the canal, T\&T is seen as a key deliverable for addressing intra-city inequality. In Johannesburg, Modderfontein has little existing development, and therefore differs from these other two, but the developers' pitch titled the project 'Modderfontein's Regeneration'. Moreover, it remains highly significant in the context of a heavily divided city attempting to fix spatial inequalities and a huge housing shortage. The success of these projects therefore has huge consequences for both the goals of local governments and for citizens.

The paper proceeds in the following way: section two addresses the mobility of urban ideas, drawing on urban and economic geography's politics of learning to highlight how knowledge is codified and learnt elsewhere. Section three discusses our methods and the process through which we built the comparison. Section four 
addresses how the idea or brand of 'King's Cross' was developed, drawing on documentary analysis and how it became a globally recognised site for sustainability and good practice. Section five then addresses our core research questions: how is the the vision of King's Cross, as an embodiment of specific urban principles, mobilised in the contexts of Brussels and Johannesburg? What does the success or failure reveal about the politics of urban expertise and the processes through which ideas travel and are learnt? Looking across these examples, the different points of reference from within the King's Cross project reveals how a set of codified ideas, the King's Cross regeneration, are reproduced selectively elsewhere. Through our comparison we highlight the global reach of projects such as King's Cross. However, looking at the different ways it is used and manifests in practice, we argue, shows the agency of developers in the context of a myriad of places international or global actors can draw upon during development processes. Moreover, we argue, in support of existing literature, for the need for developers to localise the projects or ideas they draw on, through both explicit and tacit knowledge, in order to employ them effectively.

\section{Policy Mobility Research: bringing forward the Economic Geography agenda of the politics of learning}

The processes involved in the mobilisation of urban ideas in one place and their dissemination elsewhere have been well-documented in policy mobility research (cf. example, McCann, 2008; Wood, 2014; Carolini et al., 2018). This body of work has revealed the importance of following both the policy itself, the actors (or tools, cf. Ward, 2011) behind the policy (Wood, 2014; González, 2010), and the geography of these movements (Ward, 2011; Wood, 2014; Carolini et al., 2018). Within this, research has been particularly revealing of the individuals behind the movement, as McCann notes "the need to understand and identify who mobilizes policy is crucial precisely because mobilities are social processes" (2011a: 113). However whilst this vast literature has revealed the multiplicity of policies and people involved in a somewhat globalised circulation, there needs to be a more far-reaching discussion about the embodied practices of globalised urban processes. In response, and drawing on policy mobility work, more recent research has sought to expand the lens of analysis to show the role of the private sector in moving ideas about urban development processes (Datta, 2018; Bok and Coe, 2017; Rapaport and Hult, 2017; Watson, 2013;), including the translation process (Brill, 2018; Albrecht, 2016). Such work has demonstrated the power of rhetoric and the global deployment of specific phrases or branding - the use of 'smart-' or 'eco-city' for example - by both the state and its actors, and internal to the private sector (Watson, 2015; Rapaport and Hult, 2017; van Noorloss and Kloosterboer 2018).

This research agenda is particularly pertinent given the growing role of the private sector in dictating urban development processes. This includes, for example, the vast number of consultants employed in developments, especially large scale ones like King's Cross (Robin, 2018; Raco et al., 2016), and the hiring of international consultancies (Brill, 2018) who facilitate the globalisation of design and architectural practices (Anderson and Røe, 2017). Whilst the lessons on localisation and the importance of contextualising ideas when they arrive in a new location are highly important, research currently focuses on the actors moving the ideas, often at the 
expense of engaging with how the idea itself reflects a specific politics, cultural practice or the path-dependency of urban processes from the site of leaving, and when arriving (Peck, 2011). Following Lovell (2017), we draw from economic geography's lessons on the difference between tacit (buzz or know-how) and explicit (expert or codified) knowledge to demonstrate how both are needed for effective mobility (cf. Bunnell and Coe, 2001), to examine, in part, how tacit knowledge is not merely dependent on proximity.

Prince's (2010) research on the movement of policy for 'Creative Industries' from the UK to New Zealand is particularly insightful in this respect. He reveals a two stage process of policy mobilisation, highlighting the technical and political dimensions of the travelling of global ideas or policies. In the place they are conceived policies must be defined, delineated and 'made thinkable' to be codified and rendered 'available for comparison, evaluation and policy formation' (2010: 169). Policy consultants are vital in this, especially within the technical systems that enable the dissemination of a policy through the codification of 'expert' knowledge. The success of moving a policy to elsewhere rests on political processes, where differently experienced politics result in divergent policy trajectories. Prince highlights that policies must therefore integrate in "what were regarded as the institution and cultural realities" (2010: 183, emphasis added). In phrasing mobility around perceptions of what is normal, Prince highlights the socialised nature of both ends of the mobility process. Contentious moments and the (in)ability to adapt to local socialised understandings lead to a pluralised policy trajectory. The ideas respond to the experiences on the ground and are therefore highly path-dependent (McCann, 2011). This suggests research should be attendant to the diversity of experiences when ideas 'arrive at', and one way of conceptualising this is through an international comparison of the same phenomena.

Following and developing from Prince's (2010) work, this paper seeks to continue to widen the debates on mobilities and the practices through which policies in Prince's work, and ideas in our work, travel. Specifically, we wish to highlight how ideas become intertwined in narratives about specific projects, drawing on existing research on models in motion (cf. González, 2011; Pow, 2014). For example, in Pow’s (2014) research we see the benefits of following one model to a multitude of other cases, what this reveals, and the practices and embodied expertise of those doing the moving (Pow, 2018). Learning from this, in our research we question how the creation of emblematic projects limits a deeper engagement with development processes elsewhere, often because of its 'fast' assemblage in new locations (Pow, 2014). In doing so we hope to demonstrate how the perceived embodiment of globalised standards of urban practice reduces King's Cross to an easily transportable narrative.

Further to this, as Robinson (2015) has highlighted, research on mobilities must seek to challenge traditional assumptions about where best to place the analytical gaze. In looking from the perspective of the recipient city - rather than the company responsible for moving ideas or from the city the idea left - Robinson calls for a grounded approach which recognises the diversity of experiences of policy makers and explores how local actors 'arrive at' particular policies. We follow this, and expand it to look at how actors beyond the public sector face a range of places to draw from too. In doing so we hope to reveal the almost mundane everyday 
processes Larner (2003) highlighted form the basis of globalisation. Moreover, as McCann (2011) notes, the materiality of policy transference is evident in a range of items and experiences, from speeches to emails (see also Lovell, 2017). Applying this to our cases reveals the multiplicity of ways King's Cross travels. This is particularly interesting in the context of what Côté-Roy and Moser (2018) recently conceptualised as the 'seductive' rhetoric of elite discourses, which speaks to the often symbolic importance of concepts or ideas. This in turn encourages research to question what makes an idea 'thinkable' in different cases. In the context of our comparative analysis, this works encourages us to question how seemingly diverse locations utilise similar ideas and how a project can or cannot become 'thinkable' globally through a focus on its arrival.

\section{Methodology and constructing the comparison}

This paper is based on extensive field work by the authors, including discourse analysis of media and press releases for each of the projects, project specific documentary analysis (of policies and masterplans) and over 50 interviews across the sites, with actors from the public and private sector. The cases were selected because of their size and importance, relative to their cities. Initially the projects did not seek to look at the mobilisation of King's Cross, rather this emerged inductively as a theme from the research process. In Johannesburg, the research initially focused on understanding real estate developers' motivations and strategies; in Brussels the research addressed the public political agendas enacted through T\&T. In both cases though, the analysis addressed institutional arrangements and their relationship with the motivations, strategies, and resources of the (public and private) actors involved, including the involvement of 'best practice'. Across both projects the reference to King's Cross explicitly emerged during interviews with the sites' developers. Our initial interest in understanding King's Cross responded to these references and came about as a result of conversations at conferences where we reflected on the mobilisation and use of best practices in large-scale regeneration projects. Given that King's Cross was referred to both in T\&T and Modderfontein, we questioned the extent to which project mobility may be considered a crucial component of both site's developers and consultants' strategies, and how interrogating its use can help unveil differences in developers' attitudes and motivations. As this research agenda emerged between the authors, we returned to our data and research sites, and specifically sought to address how King's Cross was utilised through new and follow-up interviews and research. These later interviews specifically addressed King's Cross' deployment, questioning why it was used and how.

On face value, T\&T perhaps has more in common with King's Cross, especially in terms of aesthetics. However, deeper interrogation demonstrates that despite this, the use of Kings' Cross in the T\&T case was looser, of perceived lesser value, and 'less formalised' than the Modderfontein case. To draw out a more thorough analysis of what this means, this paper adopts a 'comparative urbanism' approach (Robinson, 2016) which challenges us to learn across diverse outcomes, processes, and contexts (cf. Robinson and Roy, 2015). Our framework builds on key points of comparability of the sites, the reason each were chosen for the project in the first instance: both sites were imaginative ideas which sought to capitalise of specific institutionalised political narratives in their particular locations, they are both considered large or strategic by the relevant 
institutional bodies, and additionally both are projects which were under development at the time of research. Each site was pitched as a 'grand project' within their city, where both were some of the last remaining large tracts of as yet undeveloped land in their cities, as such in both cases the developers utilised international points of reference, drawing from ideas concretised through projects such as King's Cross in London. Moreover, their ideas were often associated with 'regeneration', another shared component of the projects (even if Modderfontein has limited existing development).

Building on these shared elements of development, our analysis sought to utilise a 'tracing' approach (Robinson 2016) which draws on the methodological advancements made in comparative urbanism during mobilities research (Robinson, 2018; cf. Cook and Ward, 2012; Ward, 2018). In this endeavour we sought to follow the actors, tools and narratives which enabled King's Cross to be mobilised and employed in new places. As noted above, in this respect we drew particular inspiration from existing analysis of 'projects': the Barcelona (Gonzalez, 2011) and Singapore model (Pow, 2014; 2018). Specifically, as Pow (2014) shows in the case of the Singapore model, ideas and status become enrolled as part of a toolkit for the actors doing the research and they underpin the travelling of models or ideals (cf. Cook and Ward, 2013). Following this, we therefore paid attention to similarities in our respective developers' toolkits. As such, we asked questions around what and why developers used certain points of reference, to trace the origin of their thoughts around 'best practice' and projects worth emulating. But at the same time, as previous research has shown, there are a myriad of different manifestations of 'best practice' (Rapoport, 2014). Therefore, in comparing T\&T and Modderfontein, we also looked at instances where processes diverged, as well as converged. In looking at moments of difference we were able to more thoroughly interrogate what element of the model was perceived more relevant in Brussels or Johannesburg, to analyse how the political processes impacted the project's mobility, and to identify when King's Cross was utilised by developers. This in turn allowed us also to draw conclusions on the nature, strategies, and motivations of the developers of the two projects. Such a comparative tactic, which also draws on the 'frictions' in the mobility process, helps unveil the struggles behind assembling a specific vision in a new place (Cook and Ward, 2012). In comparing across the two sites we were therefore able to more fully capture the tensions within the King's Cross model, as it travelled.

\section{How the King's Cross brand developed}

King's Cross is an inner city district in London, composed of multiple sites, which after experiencing deindustrialisation became a central site for debating London's regeneration from the 1980s. In the 1990s Foster Associates were commissioned to create a masterplan for the area which included turning the old railway lands into mainly offices (Edwards, 1991). However, this plan did not go ahead because of the recession at the time. Following this failure, in the 2000s Argent, a London-based company, were appointed as the site's chief developer. Argent created 'Principles for a Human City' (2001), an award winning scheme to transform 24 hectares of former railway and industrial lands. Their site, King's Cross Central, now hosts major international companies' head-quarters, and cultural and recreational amenities (Robin, 2018). The site also includes two 
major train stations: Kings' Cross (London and national) and St Pancras (international and national). King's Cross' redevelopment became a point of reference for developers, aided by its global prominence which was developed through two key mechanisms. Firstly, the area received awards which helped increase its international prominence and define its key characteristics. For example, Google HQ won a London Design Award for architecture, and King's Cross station was awarded 'Best Project Five Years On' and the Mayor's Award for Planning Excellence at the London Planning Awards. These helped delineate the projects' copyable dimensions, emphasising design qualities and, implicitly, the blending of the hyper modern (Google) with heritage (the station).

Secondly, the Urban Land Institute (ULI), a member-based organisation that promotes itself based on its ability to shape real estate globally through the transportation of ideas, identified King's Cross Central as a case study. In doing so, the ULI, as a global real estate expert, elevated King's Cross and enabled the narrative they selected to be transported elsewhere. ULI highlight King's Cross as: "A fully mixed-use scheme [..] an accessible, high-quality mixed-use environment with a strong focus on art, culture, and heritage" (ULI, 2014). The elements ULI highlight as part of their case study are important because ULI is the oldest and largest network of cross-disciplinary real estate and land use experts in the world. In addition to its extended analysis of Kings Cross Central, it also created a shortened version of their full case study called 'Kings Cross Station' that highlighted the station as a 'catalyst' for the wider regeneration and the 'marrying' of old and new buildings, in a way that draws attention to King's Cross as a site for transit orientated development (ToD) through the accentuation of heritage dimensions. Overall the combination of the ULI's codification of the project and the awards King's Cross Central won can be seen to have highlighted specific dimensions of the area in a way which makes the project marketable as a site to aspire to, globally.

\section{Copy-catting King's Cross: the importance of using ready-made tools}

\section{King's Cross in Brussels: when project mobility contributes to place making and place marketing strategies}

Tour and Taxis (T\&T) is a large-scale development, for an inner-city location in western Europe. The site is located in the north-west of the Brussels Capital Region, within the municipal territory of the City of Brussels, and along the canal. In this section we address how the current owner and developer, the Extensa Group, utilised King's Cross' as a point of reference in two ways. Firstly, they used King's Cross because of its heritage focus: the refurbishment of the Victorian industrial and railway buildings, and the successful combination of historic and contemporary architectures $^{1}$ (ULI, 2014). On the back of this, as in the case of King's Cross, the heritage and environmentally friendly design elements of T\&T have been turned into the new developer's branding strategies, becoming their main taglines through which they build on the uniqueness of

\footnotetext{
${ }^{1}$ King's Cross has been named as 'One of England's 20 Best Heritage-Led Development' by English Heritage for its 'model of constructive conservation that captures the special quality of London as it has grown over the centuries." (see King's Cross website: www.kingscross.co.uk/about-the-development) 
T\&T. Secondly, the story of Tour and Taxis has been 'one of complexity' (Vermeulen, 2015): the redevelopment process has been characterised by uncertainty, a large number of actors involved, diverging and sometimes conflicting planning visions, and community resistance. All these factors have extended the developer's timeframe. Responding to this, King's Cross is also referred to as a site to learn about the protracted nature of development for such large and complex, often strategic on both a local and regional and/or metropolitan level, development (Interview with the current developer \#2, 2018). To address the Extensa Group's use of King's Cross, this section utilises a historical perspective to understand how and why the heritage dimensions of T\&T evolved over time, and how this informs the idea of King's Cross as an example for the developer in more recent times.

As with King's Cross, due to its location and size, T\&T was historically considered a strategic site for the urban and economic development of its city, albeit for changing reasons over time. Throughout the twentieth century it functioned as an important logistics and transport node for the distribution of goods along the Antwerp-Brussels-Charleroi axis, and gave impetus to the industrialisation of the surrounding areas. It therefore became a symbol of the industrialisation of Brussels and, in general, of Belgium. Today the site is a symbol of the city's post-industrial transition as it steadily converts into a new innovative neighbourhood whose design combines historical buildings and modern architectures (Figure 1).

\section{[Insert Figure 1]}

Figure 1: T\&T today. Source: Author’s own (October, 2017)

After its closure as an industrial site in the 1980's, T\&T was jointly owned by a para-regional entity, the Port of Brussels, and two federal authorities, the Ministry of Finance and the railway company SNBC. These institutions were unable to create a common vision and therefore the site was left empty. Moreover, they lacked the financial resources and competences to handle such a development, given the site's position as a unique project in Brussels in terms of size and cultural heritage (Interview with regional planner \#1, 2017; Interview with the Port Authority \#2, 2018; Interview with the current Developer \#2, 2018). Within suggestions for the site at this time, interviewees noted that the restoration of existing assets was not part of the owner's 'business in the area' (Interview with a civil society association, \#2 2017; Interview with the current developer \#2, 2018). Instead, the group initially suggested the demolition and conversion of historical buildings in favour of creating a 'Music City' (1993), a project based on the idea of creating a cultural centre (see Vermeulen, 2015, Van Criekingen and Vandermotten, 2007; La Fonderie et al., 2010; BRAL, 2017).

However, the idea of destroying the historical patrimony gave rise to strong opposition by local organisations, including the Francophone Inter-Environnement Bruxelles, the Flemish BRAL, and the Atelier de Recherche et d'Action Urbaines. Guided by La Fonderie, a non-profit organisation for the promotion of the Brussels' industrial heritage, these citizens' associations proposed a counter-initiative called 'Tour and Taxis 21' which 
was still culture-centred, but privileged the preservation of existing buildings. La Fonderie engaged several international actors, such as UNESCO, Europa Nostra, the International Committee for the Industrial Heritage, and World Monument Watch (Vermeulen, 2015), and successfully 'lobbied' actors involved. Although the counter-initiative was not turned into an actual plan, it was perceived as a victory by civil society (Interview with a civil society association $\# 1,2017$ ) as it drew attention to historical patrimony ${ }^{2}$. This renewed interest in the cultural heritage of the site was then maintained when, in 2001, the Joint Venture NV Project T\&T, composed of Leasinvest NV, 100\% controlled by the Antwerp-based diversified group Ackermans and van Haaren $(\mathrm{AvH})$; Robelco NV, another Brussels developer; and IRET Development, purchased the land of the Port of Brussels and the railway company. Aware of the intrinsic historical and symbolic value of T\&T and despite existing conflicting visions on the site's future (Interview with regional planner \#1, 2018; Interview with the current developer \#2, 2018), they embraced the heritage dimension (Interview with the former developer \#2, 2018; Interview a civil society association, 2017) and signed a non-binding masterplan in 2008. In the latter, three themes were chosen to guide the redevelopment of the site: 'a re-dynamised heritage, long standing community and water' (La Fonderie et al., 2010: 89). Consequently, the idea of cultural heritage preservation became one of the cornerstones of the latest masterplan launched by the Extensa Group, a company resulting from the merger of Leasinvest NV and Extensa NV - another holding of AvH - that bought the whole area in 2015 , assembling the fragmented and divided property into one site for development.

At the same time, Brussels' institutional complexity, with overlapping planning competences between the regional government - in charge of strategic planning - and the nineteen municipalities of the Region - in charge of zoning provision (for more details see: Commission for the European Communities, 1997; Levy, 2013), slowed any attempt to push the regeneration of T\&T forward ${ }^{3}$. This partly changed in 2011 when the regional government introduced the Plan de Dévelopement Durable, aimed at addressing the socio-spatial dualisation of the city (see Kesteloot, 2000; Kesteloot and Saey, 2002; Van Criekingen and Vandermotten, 2007; Vermeulen and Corijn, 2013) and attracting investments in the so called 'North-West Crescent' (Interview with regional planner \#1, 2017), a disadvantaged and high-density area greatly affected by housing pressures and de-industrialisation (Vermeulen, 2015). The plan included the identification of new 'real estate opportunities' (Levy, 2013; 223) in ten priority zones, including T\&T and the broader Canal Zone, and the facilitation of public-private partnerhips (ibid.). In May 2017, thanks to regional pressures, the City of Brussels approved the Plan Particulier d'Affectation du Sol, paving the way for the delivery of building permits in T\&T.

At this stage in the project's development, King's Cross comes into play as a site of aspiration, beyond functioning as a comparably extended inner-city regeneration.

\footnotetext{
${ }^{2}$ In 1996, the City of Brussels appointed a French team - Reichen and Robert - who valorised heritage dimensions (La Fonderie et al., 2010; Vermeulen, 2015)

${ }^{3}$ In 2001, T\&T was included among the Zones of Regional Interest: although no clear vision was proposed for the area, some general guidelines were set for the renovation of the historical heritage. In 2010, a planning permit was delivered for $400,000 \mathrm{~m}^{2}$. Hence, the developers could initiate the regeneration of the historical buildings.
} 
"I have this reference project: King's Cross in London. It is very similar in terms of size but also because there are old and new buildings. I've been looking at the processes. [...] If you compare King's Cross to T\&T, it is perfectly comparable. My conclusion is that if you do something at this scale, it changes massively the environment. There's a lot of people involved, a lot of consequences of what you do. It takes minimum 10 years to run the process" (Interview with the current developer $\# 2,2018)$.

Importantly, it was not the only point of reference. During our interview, the former developer revealed that in the development's early days he was sintered by another London project, Broadgate, in particular in relation to design elements and the high concentration of cultural activities: "In the beginning we were inspired by Broadgate in London, for office development, but also Liverpool Station" (Interview with the former developer \#2, 2018). However, King's Cross emerged as the main source of aspiration later when King's Cross itself 'took off', and the Brussels' developer acknowledged the importance of the historical dimension for the development of T\&T. Indeed, whilst not explicitly referenced in the masterplan, across interviews with the site's current and former developers King's Cross was called upon as an explanatory point for how T\&T developed into a new space for living, working, retail, and cultural activities (Interview with the former developer \#2, 2018; Interview with the current developer \#2, 2018). Looking specifically at how the historical dimensions have been technically assembled alongside new elements and how this design scheme has been codified in King's Cross (Prince, 2010), it is possible to see how King's Cross became a symbol of heritage preservation and, therefore, thinkable in Brussels. Within this narrative, understanding how, when, and why King's Cross has been mobilised for the development of T\&T sheds light on the intrinsic connection between place making, project mobility, and branding. Taking inspiration from and referring to other projects, in this case King's Cross, was instrumental and functional to T\&T's place making/place marketing strategy. In turn this reaffirms how urban design is not only a physical process but 'encompasses social, political, and cultural processes' (Hubbard, 1996: 1445; see also Temenos and McCann, 2012) which creates new narratives and legitimises certain decisions through the space.

Moreover, the Brussels' case suggests that understanding how the connection with King's Cross played out also reveals how developers capitalise on some design elements for their branding strategies. In T\&T, the historical dimensions are considered an important asset (Interview no. 1 with regional planner, 2017; Interview with a civil society association \#1, 2017; Interview with the current developer \#2, 2018): the industrial patrimony represents, in fact, a 'business card' for the Extensa Group, a guarantee of quality to be used when promoting other projects (Interview with City Official, 2018). The approval of the last Regional Master Plan in July 2018 confirms that, as in the case of King's Cross, the regeneration of T\&T is functioning as a catalyst for the conversion of its surroundings and the broader Canal Zone (Interview with the former developer \#2, 2018; Interview with City Official \#2, 2018). All this further benefits the Extensa Group, who are major players in the Canal area as they are developing another mixed-use project - RIVA Brussels - located just across the canal, right in front of T\&T. 
In conclusion, T\&T in Brussels is an interesting case to put in conversation with Modderfontein in Johannesburg and responds to calls for the adoption of a historical approach (MacFarlane and Robinson, 2012) that seeks to capture 'the local path dependencies' and the 'range of tactics' behind project mobility (Prince, 2010: 171; cf McCann, 2011). That is to say to understand by whom, why, when, and how project mobility becomes a practice in decision-making processes in different contexts (Dolowitz and Marsh, 2000; McCann, 2011).

\section{King's Cross in Modderfontein: one of many possibilities}

Tracing King's Cross to Modderfontein shows how King's Cross was mobilised to represent, as with T\&T, an example of best practice for Atkins. However, unlike T\&T, it functioned as an example of transport orientated development $(\mathrm{ToD})$ best practice, rather than heritage-focused redevelopment. Throughout the masterplanning process, Atkins used images of King's Cross in interim reports, the eventual masterplan and meetings. Whilst to some extent this is representative of the rhetoric or even comparative thinking embedded in consultancy practices (see Rapoport, 2014), it also became a symbolic site for a key material dimension of the project: linking the project to a new train station. In Modderfontein's case, the deployment of King's Cross as a project worthy of emulating failed for two reasons: a misreading of the local context (lack of tacit knowledge) and the ineffectiveness with which it was used (inaccurately utilised explicit knowledge).

Modderfontein is strategically located with respect to (some forms of) public transport in Johannesburg. It sits along the recently developed train-line, the Gautrain, which links the airport to the centre of Johannesburg, the financial centre (Sandton) and government headquarters in Pretoria. The use of King's Cross in Modderfontein can be understood as a means of capturing the purchase around Guatrain-based ToD, as one consultant explained: "The developer had been working for at least twenty years on development plans. So there was a strong sense, strong vision, in some respects, of the notion that there would be a town centre around a Gautrain station had been embodied for a long time" (interview with architect \#2, 2017). In the first interview with Zendai in 2015, the director of development was keen to emphasise this point. She explained that they had prioritised development around the train in their plan: they ran a separate team to focus on planning permission delivery for what they termed the 'CBD' around the transport node of a new Gautrain station (Brill, 2018). The use of ToD in the CBD speaks to the long-term impact of King's Cross on Modderfontein and the longevity of the idea: in interviews with consultants two years after Atkins' workshops, ToD had stuck in their mind. All the engineers still working on the site referred to the potential of a King's Cross inspired development. As one of them explained their utilisation of ToD:

"It was a big push to focus strongly on the public transport aspects [..] looking at a light rail [Gautrain] option between the north and the city centre - and there's commuter and cargo metro rails for government trains near by. They were looking at turning one of those through the development. There was a whole load on public transport" (interview with engineer, \#1 2017). 
But for this consultant, becoming another King's Cross was a stretch, as he went on to describe how the Atkins' used King's Cross: "They were looking at a new model of living, but it's untried" (interview with engineer, \#1 2017). However, it was precisely the idea that King's Cross was a novel approach for Johannesburg that Atkins sought to exploit. The rationale for utilising King's Cross as a symbol of potentiality was rooted in how it expected to 'wow those involved' (interview with engineer \#2, 2017; interview with Zendai \#4, 2017). This was clearly articulated by the commercial consultants: "This type of development will play a critical role establishing Modderfontein as a new destination with a vibrant commercial district, a new type of residential offer, and excellent pedestrian-friendly public spaces" (Geddes and Wright, 2015: 22, emphasis added). The comparison with T\&T reveals how, in much the way the Extensa Group utilised the reference to King's Cross to highlight the importance of the historical dimension of T\&T for their commercial benefit, in Modderfontein the separation of the CBD from the more general plans is indicative of the financial importance Zendai placed on the area. The financial importance of the CBD's ToD was evident further in how it was centred in the broader masterplanning process, mimicking the language of ULI, "as a catalyst for the first development to occur" (Zendai, 2015: 336). King's Cross therefore provided a genuine source of inspiration for what the consultants perceived to be the as yet unrealised potential of Gautrain-based development, which could be established in Modderfontein.

However, in Atkins' documents, rather than utilise the codified or readable elements of King's Cross highlighted by ULI, they used loose phrasing and images and demonstrated a lack of tacit knowledge. For example, Atkins directly juxtaposed King's Cross with what they perceived to be a local failure, Rosebank Gautrain station. A photo of King's Cross in the masterplan, which emphasised elements of success: bustling people (busy but not crowded), contemporary architecture, shops and high-tech information points, was used alongside an image of Rosebank which minimised the visible development (despite its reality as an enclave of elite urban development, cf. Herbert and Murray, 2015). By putting images of King's Cross and Rosebank side by side, Atkins depicted limited versions of both sites, emphasising difference by titling the slide 'We can do better'. This employment of Kings' Cross exemplifies how it was operationalised throughout the masterplanning process - as something to generally aspire to - indicative of a politics which reinforces the necessity of Global South learning from the North, which in this case also includes a lack of tacit knowledge about Johannesburg's transit related development.

In contrast to how Atkins' juxtaposed existing Gautrain station developments with King's Cross, local consultants highlighted how Rosebank had experienced ToD, as one of the engineers working on Modderfontein explained: "ToD happened at Sandton, Rosebank and Hatfield stations. In the case of Sandton and Rosebank the commercial development almost doubled in GLA" (interview with engineer \#7, 2018). For him, the issue was not that central stations had been unable to utilise ToD as Atkins' suggested, but that to have a successful ToD site, Modderfontein needed to attract occupiers. He went on to explain: "If however someone like Zendai invests a lot to establish a major head quarter development next to the station, there is a good chance that it 
will attract other investment" (interview with engineer, 2018). Atkins simplification of King's Cross and ToD missed the nuances of existing development in Johannesburg. Moreover, the city of Johannesburg are deliberately targetting ToD (see Ballard et al., 2017) in their 'Corridors of Freedom' policy which aims to develop sites around specific corridors of public transport across the city. However, in the case of Zendai the consultants misused the Corridors of Freedom (Ballard and Harrison, 2018), demonstrating that whilst they recognized that ToD had some purchase locally, including with the planning authority, they could not adapt their strategy to effectively utilize the lessons of King's Cross.

This demonstrates that in addition to the lack of knowledge about local real estate, building on existing analysis of Modderfontein (see Ballard and Harrison, 2018; Brill, 2018), the use of King's Cross also shows Atkins' acute failure to adapt to local institutional settings. In general, one interviewee explained: "One of my big problems with the general layout with the document is that it's very long and supposedly detailed, but it has almost no pictures of the actual layout of the thing" (interview with CoJ \#1, 2017). For him the lack of detail demonstrated a lack of knowledge about the policy context and how the plan would fit within it, as well as an inability to meet CoJ's expectations. Of particular importance was how the types of ideas mobilised through the King's Cross example demonstrated Atkins' lack of understanding about how transport and sustainability agendas interlink in a Johannesburg context. The Modderfontein design failed to fully integrate transit-related sustainability agendas through to design components; ToD was instead mainly used to create (and capture through property) land value uplift. This was important because at the time CoJ was drawing up a new Strategic Framework which "argues is that to make a city suitable [environmentally] it's more about the shape and size the thing - a very sprawled city is inefficient no matter if you've got solar panels on the roofs - because people have to drive" (interview with City \#1, 2017). From CoJ's perspective, despite the use of ToD, Atkins' design emphasised driving. Looking from T\&T and King's Cross itself to Modderfontein show how such a failure was particularly acute because CoJ's policy agenda could have been addressed had Atkins used the ULI case study.

Indeed, what is particularly interesting in terms of understanding King's Cross in Modderfontein is that King's Cross was never meant to be purely a site of $\mathrm{ToD}$, rather its strength was around sustainability (including transport). As the ULI (2014) report highlights, transport was an important stimulus for King's Cross, as UK's main high-speed international train station, but this drove a need to upgrade the underground station rather than centring the entire development around the station: "People come before traffic" (ULI, 2014: 9). This people-orientated development necessitated understanding wider transport logistics such as pedestrians and bike rentals, rather than focusing on commercial development around the train station as Atkins employed King's Cross to mean. This demonstrated Atkins' lack of explicit or expert knowledge and whilst "there's been a lot of kind of movement in South Africa in the last couple of years, in terms of transit oriented development" (interview with consultant \#2, 2017), ToD emerges as a global trend Atkins' sought to leverage through a reductive employment of King's Cross. As a Modderfontein consultant from London explained: "The whole world is using the public transport and frankly the developers now understand that" (interview with engineer, 
\#1 2017). Consequently, whilst for Atkins consultants based in London King's Cross may have seemed an obvious choice for inspiration, the lack of 'easily readable' justification during its employment in Modderfontein undermined that dimension of their masterplan and fed into their failure to secure their position as experts capable of translating ideas (Pow, 2018). Moreover, whilst the example of King's Cross was associated with an attractive design and the utilization of transit's potential, it was also dependent on a strong economic base and its centrality in London. In contrast, in Modderfontein the site has little existing development and a currently weak commercial base. As such, King's Cross' inapplicability is further complicated by the different economic contexts and potential, which render Atkins' deployment of it as an example to emulate extremely aspirational.

On a final note, it is important to recognise that King's Cross was just one example Atkins drew on, but one which during interviews they were particularly keen to highlight. In the final plan submitted to the City, the consultants drew very explicitly on other London sites (but did not position these as London, just named buildings), on smaller town's in the UK, Edinburgh, Sao Paulo and what Atkins considered a 'similar project in the middle east'. This is demonstrative of how King's Cross was one of a myriad of options - it is part of the rhetorical devices deployed to perform their form of urban expertise. As Robinson (2015) argues, those on the receiving end of policy, in her case in Johannesburg, are faced with a wide range of possibilities and over time they adopt the language of other policies and it's this incremental process of choosing from various locations which means they 'pick' a policy - or as she frames it 'arrive at'. This is also true of the private sector: when they begin the planning application process, their experiences inform their choices. Design is not necessarily a top-down process driven by global elites, rather it can be formed through the everyday processes, through constant interaction with outside ideas and research - arguably, the learning of tacit knowledge. In the example of Modderfontein it is possible to see how the attempt by a global consultant to reassemble a specific form of urbanism from another location in their masterplan, which they in turn hoped would shape the City's strategic plan, failed because they were not faced with only one perspective. Instead, they were well informed by a variety of international and national perspectives on best practice which they failed to effectively utilise. In this regard, King's Cross can be understood as a symbolic, evocative point of reference for them rather than a more precisely referenced model of development.

\section{Conclusion}

This comparison of T\&T and Modderfontein highlights three main conclusions about the complexity of project mobility and the politics of what ideas are copied or inspire other projects, how and when ideas are copied, and the kind of knowledge required to replicate urban ideas in new places. Firstly, the use of the same 'model' in both T\&T and Modderfontein demonstrate the global reach of ideas. However, the tensions revealed through the comparison demonstrate the agency of private developers, building on ideas advanced in research on developers interaction with international capital (Halbert and Rouanet, 2014) or non-local actors (Halbert and David, 2016; Weber, 2010). Whilst in T\&T the developer utilised King's Cross for its heritage dimension and 
as an example of the protracted nature of development, in Modderfontein it was deployed in a very technical way: to specifically target the ToD element. The contrasting elements highlights the patchwork quilt of urban ideas which can be drawn on to form projects elsewhere. Moreover, it demonstrates how agency is facilitated not just by the localised nature of real estate (Weber, 2010; Attuyer et al., 2014) (although that is vital), but also by the potentiality of multiple points of reference in highly globalised settings. The ability to draw on and across different global points of reference enables developers and their consultants to craft projects in line with their specific visioning, mobilising different elements of international projects depending on their own visions.

This leads to the second conclusion, the necessity of localising global actors during idea mobility, which directly builds on research on the politics of learning from economic geography. This was particularly evident through the comparison: looking at the similarities of the cases, especially tracing the use of the same idea, uncovered clear differences between the sites which helped explain the different manifestations of King's Cross in practice. Through the comparison, we show how utilising King's Cross was dependent on the coherence of its design ideas during its movement. Whilst, developers evidently have agency in where they draw from, the extent to which they are successful in their references is dependent on them having both explicit expert knowledge on how the project was conceptualised and implemented in its home (in this case London), and tacit knowledge of both the place the project was implemented and of the 'arriving' destination. The latter is, as the case of T\&T in Brussels illustrates, dependent on the embeddedness of the developers. In Brussels, one of the main pillars of the Extent Group's philosophy is 'being local': the company recognises the importance of having a specific expertise of the context in which its projects are implemented (Interview with the current developer \#1, 2018). This was not the case in Johannesburg: neither the developer nor the consultants were from Johannesburg (Ballard and Harrison, 2018; Brill, 2018) and the actors always referred to King's Cross in a very explicit ways. The comparison across these sites therefore shows that the use of specific points of reference is one tool in the developer's (early, branding, public relations orientated) box, rather than a guaranteed successful strategy. Taking this further, the example of Modderfontein highlights how even proximity to the original idea does not guarantee the developer is capable of leveraging this idea. Atkins had both spatial proximity and team members who worked for a firm involved in the project (Arup worked on King's Cross), but these were not enough to ensure an understanding of how to mobilise the idea successfully. This suggests there is a need for future research to engage with intra-firm learning processes of tacit knowledge too.

Finally, theoretically, building on existing mobilities research, we seek to highlight how 'following the (loosely conceptualised) project' not only opens up the lens of analysis to address new ways of copying within urban practice but develops ideas around the importance of contextualised understandings. In doing so it specifically broadens Robinson's (2015) call to understand policy mobility in the context of the myriad of options available to contemporary policy-makers, and asks us to think about how the private sector and specifically developers, when faced with a vast number of projects to reference, decide which is most important. In doing so the projectbased approach forces us to question how private sector actors pick references based on the symbolic power of a project or on the realities the project experienced and the way it faced these. 


\section{Bibliography:}

Albrecht M, Caloffi A, Pryke S, Sedita, SR, and Siemiatycki M (2017). The role of translation loops in policy mutation processes: State designated Bioenergy Regions in Germany. Environment and Planning C: Politics and Space, 35(5), 898-915. doi:10.1177/0263774X16669354

Andersen B, and Røe PG. (2017). The social context and politics of large scale urban architecture: Investigating the design of Barcode, Oslo. European Urban and Regional Studies, 24(3), 304-317. doi:10.1177/0969776416643751

Ballard R, Dittgen R, Harrison P, and Todes A (2017). Megaprojects and urban visions: Johannesburg's Corridors of Freedom and Modderfontein. Transformation: Critical Perspectives on Southern Africa, 95(1), 111139.

Ballard, R. \& Harrison, P. (2018). 'Transnational urbanism interrupted: Chinese investors seeking approval to build the "New York of Africa" at Modderfontein'. Cape Town: African Centre for Cities International Urban Conference, 1 February

Bok R, and Coe NM (2017). Geographies of policy knowledge: The state and corporate dimensions of contemporary policy mobilities. Cities, 63, 51-57. doi:10.1016/j.cities.2017.01.001

BRAL (2017). Tour and Taxis. Online at: https://bral.brussels/nl/artikel/publicatie-thurn-en-taxis

Brill F (2018). Playing the game: A comparison of international actors in real estate development in Modderfontein, Johannesburg and London's Royal Docks. Geoforum. doi:10.1016/j.geoforum.2018.05.015

Bunnell TG and Coe NM (2001) Spaces and scales of innovation. Progress in Human Geography, 25(4): 56989

Carolini G, Gallagher D, and Cruxên I (2018). The promise of proximity: The politics of knowledge and learning in South-South cooperation between water operators. Environment and Planning C: Politics and Space. doi:10.1177/2399654418776972

Commission of the European Communities (1997), The EU Compendium of Spatial Planning Systems and Policies, Luxembourg: Office for Official Publications of the European Communities. Online at: http://commin.org/upload/Glossaries/European_Glossary/EU_compendium_No_28_of_1997.pdf

Cook, I., \& Ward, K. (2012). Relational Comparisons: The Assembling of Cleveland's Waterfront Plan. Urban Geography, 33(6), 774-795. DOI: 10.2747/0272-3638.33.6.774

Côté-Roy, L., \& Moser, S. (2018). 'Does Africa not deserve shiny new cities?' The power of seductive rhetoric around new cities in Africa. Urban Studies. https://doi.org/ 10.1177/0042098018793032

Crivello S (2015) Urban Policy Mobilities: The Case of Turin as a Smart City, European Planning Studies, 23:5, 909-921, DOI: 10.1080/09654313.2014.891568

Dittgen R (2017). Features of Modernity, Development and 'Orientalism': Reading Johannesburg through its ' Chinese' Urban Spaces. Journal of Southern African Studies 43(5).

Dolowitz D Marsh D (2000). Learning from Abroad: The Role of Policy Transfer in Contemporary PolicyMaking, Governance: An International Journal of Policy and Administration, 13(1), 5-25 
Geddes, D., \& Wright, C. (2015). Modderfontein Commercial Development Framework (Rep.). London: COLLIERS INTERNATIONAL PROPERTY ADVISERS UK LLP.

Gonzalez S (2011). Bilbao and Barcelona 'in Motion'. How Urban Regeneration 'Models' Travel and Mutate in the Global Flows of Policy Tourism. Urban studies, 48(7), 1397-1397.

Halbert L and Rouanet H (2014). Filtering Risk Away: Global Finance Capital, Transcalar Territorial Networks and the (Un)Making of City-Regions: An Analysis of Business Property Development in Bangalore, India. Regional Studies, 48(3), 471-484. doi:10.1080/00343404.2013.779658

Herbert CW and Murray MJ (2015) 'Building from scratch: new cities, privatized urbanism and the spatial restructuring of Johannesburg after apartheid', International Journal of Urban and Regional Research 39: 471-94.

Hubbard P (1996), Urban Design and City Regeneration: Social Representations of Entrepreneurial Lanscapes. Urban Studies, Vol. 33, No. 8, 1441-1461.

La Fonderie, Tour \& Taxis, Culture and Cultural Heritage Department of the Ministry of the French Speaking Community Wallonia-Bruxelles (2010), 'Tour \& Taxis: Un Quartier en Mouvement, Racine.

Larner W (2003) Neoliberalism? Environment and Planning D: Society and Space, 21: 509-512.(Vol. 21, pp. 509-512).

Levy S (2013). A Brief History of Planning Instruments in Corijn, E., van de Ven, J. (eds) The Brussels Reader: A Small World City to Become the Capital of Europe, VUBpress Brussels University Press, Brussels

Lovell H (2017) Policy failure mobilities, Progress in Human Geography pp. 1-18 DOI: $10.1177 / 0309132517734074$

Kesteloot C (2000). Brussels, Post-Fordist Polarization in a Fordist Spatial Canvas in Marcuse P., van Kempen R. (eds.), Globalizing cities, a new spatial order?, Blackwell Publishers, London, 187-210

Kesteloot C and Saey P (2003). Brussels, A Truncated Metropolis. GeoJournal, 58, 53-63.

McCann E (2011). Urban Policy Mobilities and Global Circuits of Knowledge: Toward a Research Agenda. Annals of the Association of American Geographers, 101(1), 107-130. doi:10.1080/00045608.2010.520219

McCann E and Ward K (2012). Policy Assemblages, Mobilities and Mutations: Toward a Multidisciplinary Conversation. Political Studies Review, 10(3), 325-332. doi:10.1111/j.1478-9302.2012.00276.x

McCann E and Ward K (2015). Thinking Through Dualisms in Urban Policy Mobilities. International Journal of Urban and Regional Research, 39(4), 828-830. doi:10.1111/1468-2427.12254

McCann EJ (2008). Expertise, Truth, and Urban Policy Mobilities: Global Circuits of Knowledge in the Development of Vancouver, Canada's ‘four Pillar' Drug Strategy. Environment and Planning A, 40(4), 885-904. doi:10.1068/a38456

McCann EJ (2011) Urban Policy Mobilities and Global Circuits of Knowledge: Toward a Research Agenda, Annals of the Association of American Geographers, 101:1, 107-130, DOI: 10.1080/00045608.2010.520219 McFarlane C Robinson J (2012). Introduction- Experiments in Comparative Urbanism, Urban Geography, 33(6), 765-773.

Peck J (2011) 'Geographies of policy: from transfer-diffusion to mobility-mutation' Progress in Human Geography 35(6), 773-797

Pow C.P. (2014) License to travel, City, 18:3, 287-306, DOI: 10.1080/13604813.2014.908515 
Pow, C. P. (2018) 'Constructing authority: embodied expertise, homegrown neoliberalism and the globalization of Singapore's private planning', Environment \& Planning A, https://doi.org/ 10.1177/0308518X18778036

Prince R (2010). Policy Transfer as Policy Assemblage: Making Policy for the Creative Industries in New Zealand. Environment and Planning A, 42(1), 169-186. doi:10.1068/a4224

Raco M, Street E and Freire-Trigo S (2016). The New Localism, Anti-Political Development Machines, and the Role of Planning Consultants: Lessons from London's South Bank. Territory, Politics, Governance , 4 (2) pp. 216-240. (2016).

Rapoport E and Hult A (2017). The travelling business of sustainable urbanism: International consultants as norm-setters. Environment and Planning A, 49(8), 1779-1796. doi:10.1177/0308518X16686069

Robin E (2018). Performing real estate value(s): real estate developers, systems of expertise and the production of space. Geoforum. doi:10.1016/j.geoforum.2018.05.006

Robinson J (2008). Developing Ordinary Cities: City Visioning Processes in Durban and Johannesburg. Environment and Planning A, 40(1), 74-87. doi:10.1068/a39127

Robinson J (2015). 'Arriving At' Urban Policies: The Topological Spaces of Urban Policy Mobility. International Journal of Urban and Regional Research, 39(4), 831-834. doi:10.1111/1468-2427.12255

Robinson, J. (2016). Thinking cities through elsewhere: Comparative tactics for a more global urban studies. Progress in Human Geography, 40, 1: 3-29

Robinson, J. (2018). Policy mobilities as comparison: urbanization processes, repeated instances, topologies. Revista de Administração Pública, 52(2), 221-243. https://dx.doi.org/ 10.1590/0034-761220180126

Robinson J and Roy A (2015). Global Urbanism and the Nature of Urban Theory, International Journal of Urban and Regional Research. doi: 10.1111/1468-2427.12272

Swingedouw E and Baeten G (2010). Scaling the city: the political economy of Glocal Development_Brussels Conundrum, European Planning Studies, 9(7), 827-849

Temenos C and McCann E. (2012). The Local Politics of Policy Mobility:Learning, Persuasion, and the Production of a Municipal Sustainable Fix. Environment and Planning A, Vol. 44, Issue, 6.

Urban Land Institute. (2014) ULI Case Studies. available at: http://casestudies.uli.org/kings-cross van Noorloos F and Kloosterboer M (2018). Africa's new cities: The contested future of urbanisation. Urban Studies, 55(6), 1223-1241. doi:10.1177/0042098017700574

Van Criekingen M and Vandermotten C (2007). Brussels Tour and Taxis: Entrepeneurship versus the Fragmented City in Salet. W., Gualini, E. (eds.) Framing Strategic Urban Projects: Learning from Current Experiences in European Urban Region, London, Routledge, pp. 146-171

Vermeulen S and Corijn E (2013) Gentrification or Upward Social Mobility in Corijn, E., van de Ven, J. (eds) The Brussels Reader: A Small World City to Become the Capital of Europe, VUBpress Brussels University Press, Brussels

Vermeulen S (2015). The Brussels Canal Zone: Negotiating Visions for Urban Planning, VUBpress Brussels University Press, Brussels 
Ward K (2011). Applied policy research and critical human geography. Dialogues in Human Geography, 1(2), 238-241. doi:10.1177/2043820611404496

Ward, K. (2018). Policy mobilities, politics and place: The making of financial urban futures. European Urban and Regional Studies, 25(3), 266-283. https://doi.org/ 10.1177/0969776417731405

Watson V (2014). African urban fantasies: dreams or nightmares? Environment and Urbanization, 26(1), 215231. doi:10.1177/0956247813513705

Weber R (2010). Selling City Futures: The Financialization of Urban Redevelopment Policy. Economic Geography, 86(3), 251-274. doi:10.1111/j.1944-8287.2010.01077.x

Wood A (2014). Learning through Policy Tourism: Circulating Bus Rapid Transit from South America to South Africa. Environment and Planning A, 46(11), 2654-2669. doi:10.1068/a140016p 